\title{
Freshwater discharge controlled deposition of Cenomanian-Turonian black shales on the NW European epicontinental shelf (Wunstorf, northern Germany)
}

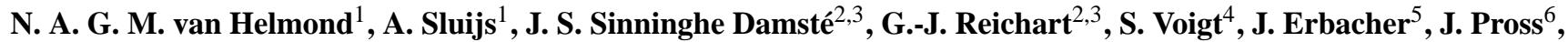 \\ and $\mathbf{H}$. Brinkhuis ${ }^{1,3}$ \\ ${ }^{1}$ Marine Palynology and Paleoceanography, Laboratory of Palaeobotany and Palynology, Department of Earth Sciences, \\ Faculty of Geosciences, Utrecht University, Budapestlaan 4, 3584 CD Utrecht, the Netherlands \\ ${ }^{2}$ Department of Earth Sciences, Faculty of Geosciences, Utrecht University, Budapestlaan 4, \\ 3584 CD Utrecht, the Netherlands \\ ${ }^{3}$ NIOZ, Royal Netherlands Institute for Sea Research, P.O. Box 59, 1790 AB Den Burg, Texel, the Netherlands \\ ${ }^{4}$ Institute of Geosciences, Goethe University Frankfurt, Altenhöferallee 1, 60438 Frankfurt, Germany \\ ${ }^{5}$ Bundesanstalt für Geowissenschaften und Rohstoffe, P.O. Box 5101 53, Alfred-Benz-Haus, Stilleweg 2, \\ 30641 Hanover, Germany \\ ${ }^{6}$ Paleoenvironmental Dynamics Group, Institute of Earth Sciences, University of Heidelberg, Im Neuenheimer Feld 234, \\ 69120 Heidelberg, Germany
}

Correspondence to: N. A. G. M. van Helmond (n.vanhelmond@uu.nl)

Received: 13 August 2014 - Published in Clim. Past Discuss.: 12 September 2014

Revised: 9 February 2015 - Accepted: 23 February 2015 - Published: 18 March 2015

\begin{abstract}
Global warming, changes in the hydrological cycle and enhanced marine primary productivity all have been invoked as having contributed to the occurrence of widespread ocean anoxia during the Cenomanian-Turonian oceanic anoxic event (OAE2; 94 Ma), but disentangling these factors on a regional scale has remained problematic. In an attempt to separate these forcing factors, we generated palynological and organic geochemical records using a core spanning the OAE2 from Wunstorf, Lower Saxony Basin (LSB; northern Germany), which exhibits cyclic black shale-marl alternations related to the orbital precession cycle.

Despite the widely varying depositional conditions complicating the interpretation of the obtained records, $\mathrm{TEX}_{86}^{\mathrm{H}}$ indicates that sea-surface temperature (SST) evolution in the LSB during OAE2 resembles that of previously studied sites throughout the proto-North Atlantic. Cooling during the socalled Plenus Cold Event interrupted black shale deposition during the early stages of OAE2. However, TEX $\mathrm{X}_{86}$ does not vary significantly across black shale-marl alternations, suggesting that temperature variations did not force the forma-
\end{abstract}

tion of the cyclic black shale horizons. Relative (i.e., with respect to marine palynomorphs) and absolute abundances of pollen and spores are elevated during phases of black shale deposition, indicative of enhanced precipitation and run-off. High abundances of cysts from inferred heterotrophic and euryhaline dinoflagellates supports high run-off, which likely introduced additional nutrients to the epicontinental shelf resulting in elevated marine primary productivity.

We conclude that orbitally forced enhanced precipitation and run-off, in tandem with elevated marine primary productivity, were critical in cyclic black shale formation on the northern European epicontinental shelf and potentially for other OAE2 sections in the proto-Atlantic and Western Interior Seaway at similar latitudes as well.

\section{Introduction}

Dark, often laminated marine sediments that are usually devoid of fossil traces of benthic life and exhibit a total organic carbon (TOC) content of $>1 \%$ (Creaney and Passey, 


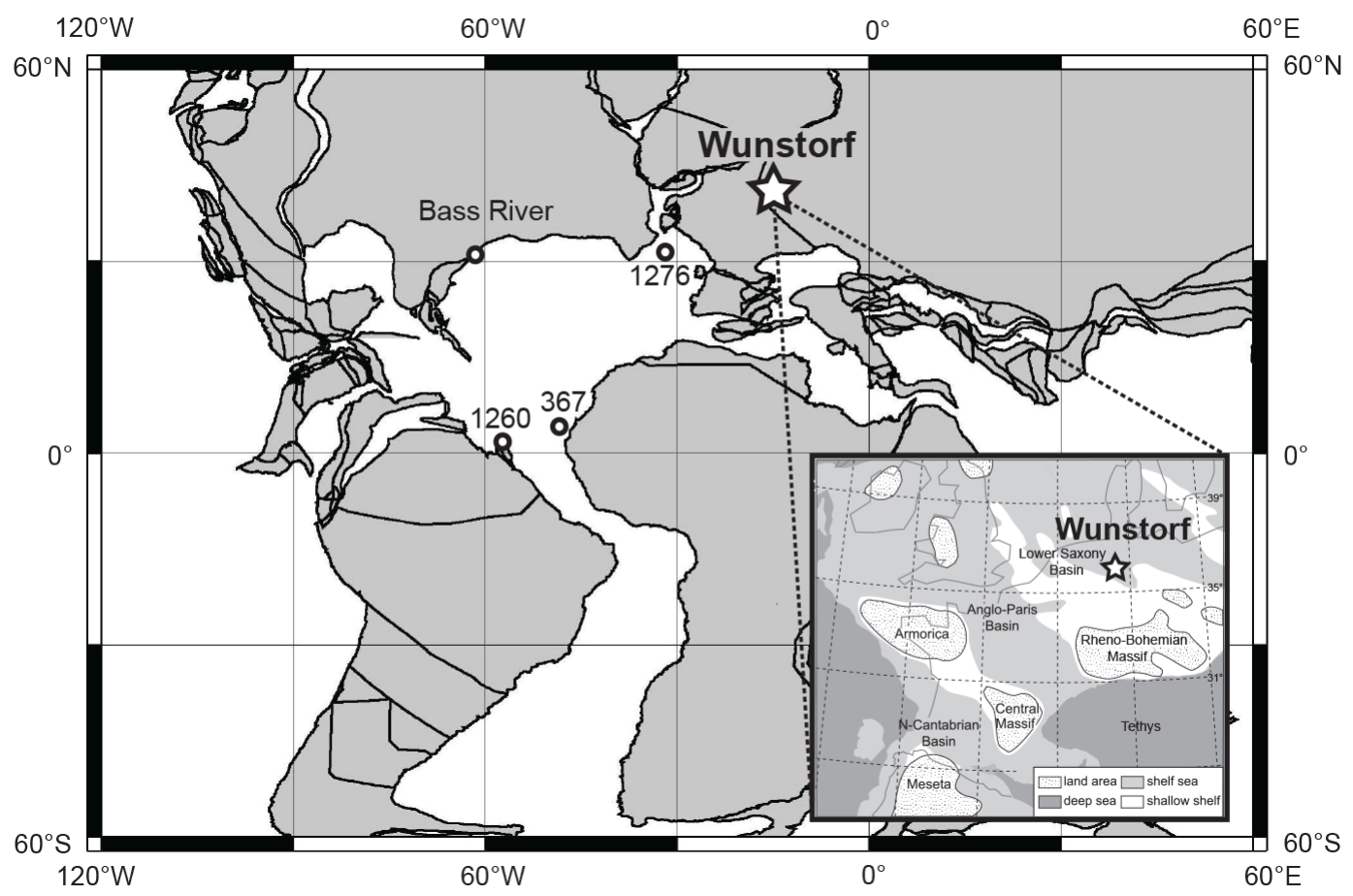

Figure 1. Paleotectonic reconstruction for the Cenomanian-Turonian boundary time interval, with the location of the Wunstorf core and sections with previously published TEX $_{86}$-based SST records: Bass River, DSDP site 367 and ODP sites 1260 and 1276 indicated (map generated at http://www.odsn.de/odsn/services/paleomap/paleomap.html). Inset map shows a detailed paleogeographic reconstruction of central and western Europe, including the location of the Wunstorf core (modified from Voigt et al., 2004).

1993) were episodically deposited during the Jurassic and Cretaceous. The deposition of these sediments, generally referred to as black shales, has typically been taken to indicate ancient episodes of dysoxic or anoxic bottom water conditions (Schlanger and Jenkyns, 1976). During some of these episodes, anoxia occurred widely across one or more ocean basins; such episodes were termed oceanic anoxic events (OAEs; Schlanger and Jenkyns, 1976). One of the most prominent, best-constrained and best-studied of these OAEs formed across the Cenomanian-Turonian boundary (CTB; $\sim 94 \mathrm{Ma}$ ) and is known as OAE2 (e.g., Jenkyns, 2010). The widespread enhanced organic carbon burial in marine sediments during OAE2 is expressed by a worldwide documented $>2 \%$ opsitive carbon isotopic excursion (CIE) of carbonate $\left(\delta^{13} \mathrm{C}_{\text {carb }}\right)$ and organic matter $\left(\delta^{13} \mathrm{C}_{\mathrm{org}}\right)$, with an estimated duration of 450-600 kyr (e.g., Voigt et al., 2008; Meyers et al., 2012). This CIE likely resulted from enhanced burial of $\delta^{13} \mathrm{C}$-depleted organic matter (Arthur et al., 1988; Tsikos et al., 2004) and therefore provides a C-isotopic signature of the global exogenic carbon pool, making it a proper tool to confidently correlate OAE2 sections.

Over the past several decades, many studies have been conducted to unravel the processes responsible for this massive burial of organic carbon during OAEs, and OAE2 in particular. Extensive volcanism close to the CTB (e.g., Snow et al., 2005; Kuroda et al., 2007; Turgeon and Creaser, 2008) has been linked to high levels of atmospheric $\mathrm{CO}_{2}$ (e.g., Schouten et al., 2003; Sinninghe Damsté et al., 2008; Barclay et al., 2010), raising the temperatures of already warm oceans towards a maximum at the onset of OAE2 (e.g., Bice et al., 2006; Forster et al., 2007), which reduced the solubility of oxygen in surface waters. This warming caused an enhanced hydrological cycle (van Helmond et al., 2014), which would likely have contributed to increased rates of continental weathering and runoff (Blätter et al., 2011; Pogge von Strandmann et al., 2013). This, in turn would have led to at least seasonal stratification and enhanced nutrient supply to continental margins and epicontinental seas. Extensive volcanism may also have directly contributed to ocean fertilization (Kerr et al., 1998; Snow et al., 2005), while changes in proto-Atlantic circulation may have increased the strength of upwelling (e.g., Poulsen et al., 2001; Junium and Arthur, 2007). Enhanced regeneration of sedimentary phosphorus from dysoxic and anoxic sediments (e.g., Kuypers et al., 2004b; Mort et al., 2007) combined with abundant nitrogenfixing cyanobacteria (Kuypers et al., 2004b) may have sustained high levels of primary productivity. All of the above factors would have driven the expansion of oxygen minimum zones and oxygen depletion of bottom waters, leading to enhanced organic carbon burial.

As a result of late Cenomanian sea level rise (e.g., Erbacher et al., 1996; Voigt et al., 2006), large parts of con- 
tinents became flooded, greatly expanding the extent of epicontinental shelf seas where sediments recording the OAE2 were deposited. In particular, the Lower Saxony Basin (LSB; northern Germany) exhibits expanded and complete OAE2 successions (Wilmsen, 2003) containing several cyclic alternations of organic-poor marls, limestones and organic-rich black shales (Voigt et al., 2008). Organic matter accumulation on the European shelf was relatively modest, however, compared with other cyclic OAE2 sections in the protoAtlantic (Kuypers et al, 2004a; Forster et al., 2008).

The complete OAE2 interval has been recovered from the LSB through coring at Wunstorf (Erbacher et al., 2007; northern Germany; Fig. 1). Application of an orbital cyclebased age model has shown that black shale deposition in the Wunstorf core sediments is consistent with precession forcing (Voigt et al., 2008). This implies that climate change resulting from orbital fluctuations was directly related to phases of black shale deposition. The robust cyclostratigraphy and biostratigraphic zonation of the Wunstorf core allows for a high-resolution study of astronomically induced climate change. Here we aim to reconstruct mean annual sea surface temperature (SST), hydrological changes and marine primary productivity, to determine the dominant control on decreasing oxygen concentrations during OAE2 on the European shelf. To this end, we combined organic geochemical $\left(\right.$ TEX $_{86}$; BIT index) and palynological proxies, notably organic-walled dinoflagellate cysts (dinocysts) and pollen and spore abundances across the CTB for the Wunstorf core.

\section{Material and methods}

\subsection{Site description, depositional setting and age model}

The Wunstorf core was drilled in $2006 \sim 25 \mathrm{~km}$ west of Hanover, Germany $\left(52^{\circ} 24.187^{\prime}\right.$ N, $9^{\circ} 29.398^{\prime \prime}$ E, Voigt et al., 2008; Fig. 1). Approximately $76 \mathrm{~m}$ of middle Cenomanian to middle Turonian sediments, comprising a $\sim 13.5 \mathrm{~m}$ thick CTB succession, were retrieved. During the Late Cretaceous, the drill site was located in the LSB, which was part of the expanded epicontinental shelf sea that covered most of Eurasia after the Cenomanian transgression (Hancock and Kauffman, 1979). The sediments at Wunstorf were deposited at an estimated water depth of $100-150 \mathrm{~m}$ based on sequence stratigraphy, sedimentological analysis and (micro)fossil content (Wilmsen, 2003). The most proximal exposed land, the Bohemian Massif, was located $\sim 150 \mathrm{~km}$ to the south and formed a barrier towards the western Tethys. The Armorican and British massifs formed a barrier towards the Atlantic, while the Fennoscandian Shield formed a barrier to the open ocean to the north (Fig. 1; Wilmsen, 2003).

The OAE2 interval at Wunstorf is part of the Hesseltal formation and occurs between 49.6 and $23.1 \mathrm{~m}$ below surface (mbs). The Hesseltal formation consists of rhythmically alternating couplets of finely laminated black shales with ele- vated levels of total organic carbon (TOC; max. $2.8 \%$; Hetzel et al., 2011; Fig. 2b), grey to green marls, and light grey (marly) limestones (Fig. 2; Erbacher et al., 2007; Voigt et al., 2008). The cyclic lithology results from a depositional system greatly influenced by precession (Voigt et al., 2008). Biostratigraphic zonation for the Hesseltal Formation relies on inoceramids, ammonites, acme occurrences of macrofossils and planktonic foraminifera that can be reliably correlated regionally and globally (Ernst et al., 1984; Voigt et al., 2008, and references therein).

The onset of the OAE2 interval is primarily based on the first occurrence (FO) of the ammonite Metoicoceras geslinianum at $49.6 \mathrm{mbs}$, consistent with the English Chalk (Voigt et al., 2008). At $47.8 \mathrm{mbs}$, the onset of the characteristic positive shift in $\delta^{13} \mathrm{C}_{\text {carb }}(\sim 2 \%$ o $)$ and $\delta^{13} \mathrm{C}_{\text {org }}(\sim 2.5 \%)$ has been recognized (Voigt et al., 2008; Du Vivier et al., 2014; Fig. 2a). The termination of the OAE2 interval at Wunstorf was placed at $36 \mathrm{mbs}$ (Voigt et al., 2008). The duration of the OAE2 for the Wunstorf core was estimated as $\sim 435 \mathrm{kyr}$ or $\sim 500 \mathrm{kyr}$ based on spectral analysis of the lithological cyclicity and $\delta^{13} \mathrm{C}_{\text {org }}$, respectively (Voigt et al., 2008; Du Vivier et al., 2014).

\subsection{Total organic carbon analysis}

About $0.3 \mathrm{~g}$ of freeze-dried and powdered sediment sample was decalcified using $1 \mathrm{M} \mathrm{HCl}$, followed by rinsing with demineralized water and drying again. Total organic carbon (TOC) concentrations were measured using a Fisons Instruments CNS NA 1500 analyzer and corrected for weight loss during decalcification. Results were normalized to in-house standard of acetanilide, atropine and nicotinamide. The average analytical uncertainty based on duplicate analysis of sediment samples was 0.04 weight percent (wt \%).

\subsection{Organic geochemistry}

For 48 samples, biomarkers were extracted from $10-15 \mathrm{~g}$ of powdered and freeze-dried sediments with a Dionex accelerated solvent extractor (ASE) using a dichloromethane (DCM)/methanol mixture $(9: 1, v / v)$. Total lipid extracts (TLEs) were evaporated to near dryness using rotary evaporation. Subsequently, remaining solvents were removed under a nitrogen flow. The TLEs were separated by $\mathrm{Al}_{2} \mathrm{O}_{3}$ column chromatography into apolar, ketone, glycerol dialkyl glycerol tetraether (GDGT) and polar fractions using three column volumes of the eluents hexane/DCM $(9: 1, v / v)$, ethyl acetate $(v)$, DCM / methanol $(95: 5, v / v)$ and DCM/methanol $(1: 1, v / v)$, respectively. The apolar and GDGT fractions were dried under a nitrogen flow and weighed. The apolar fractions of two samples (41.14 and $42.81 \mathrm{mbs}$ ), selected based on their high yield, were measured using gas chromatography mass spectrometry (GCMS), to determine the thermal maturity of the sediments based on the degree of isomerization of hopanes. Only two 


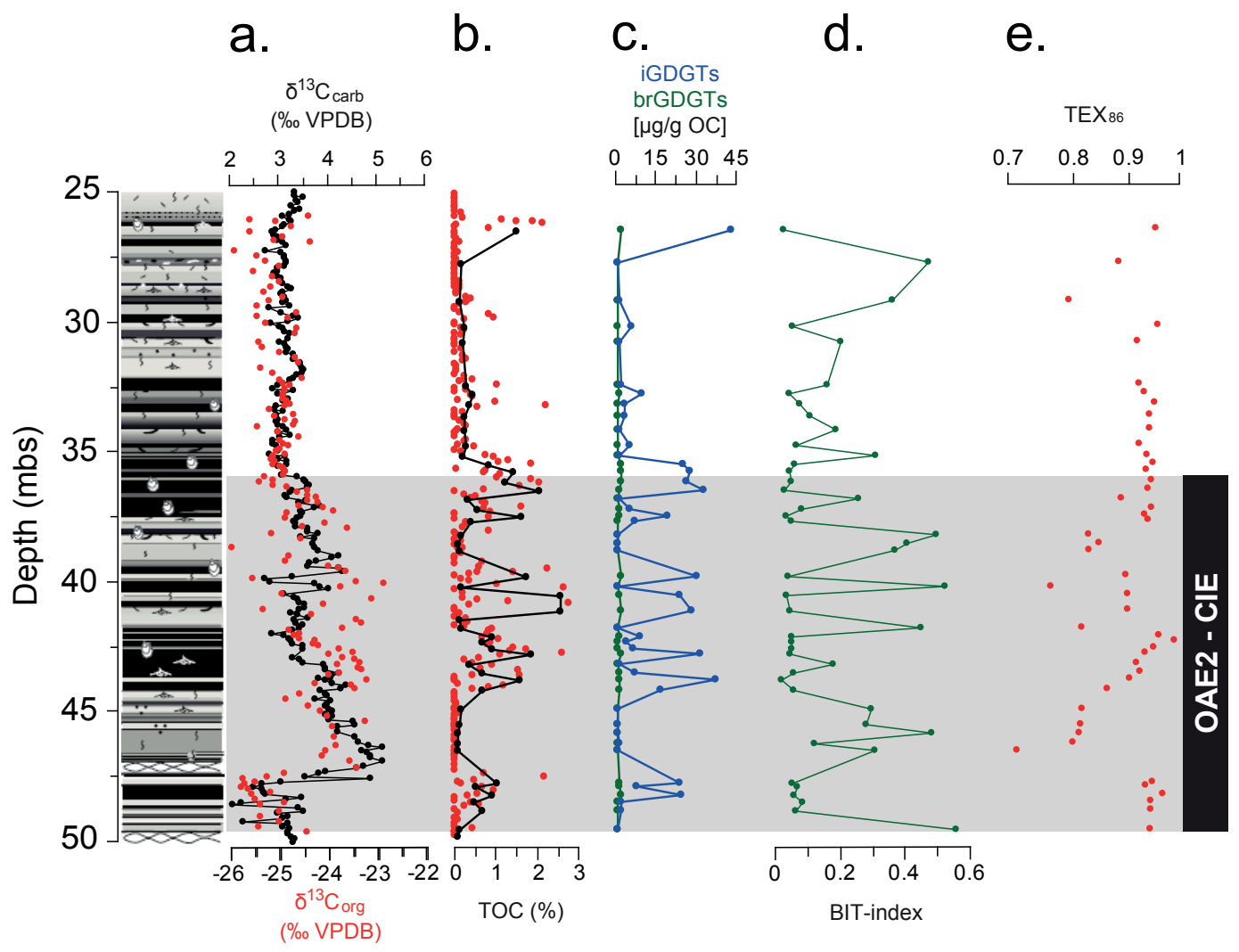

Figure 2. Geochemical results for the Cenomanian-Turonian transition of the Wunstorf core. Stratigraphy from Voigt et al. (2008). (a) $\delta^{13} \mathrm{C}_{\mathrm{carb}}$ (Voigt et al., 2008) and $\delta^{13} \mathrm{C}_{\mathrm{org}}$ (du Vivier et al., 2014; red). (b) Total organic carbon (TOC: black, this study; red, Hetzel et al., 2011). (c) Concentrations of summed iGDGTs and summed brGDGTs ( $\mu \mathrm{gg}^{-1}$ OC). (d) BIT index. (e) TEX 86 values. The grey zone indicates the OAE2 interval after Voigt et al. (2008).

samples were analyzed because it is very unlikely that the degree of thermal maturity will change over a distance of $25 \mathrm{~m}$ (difference in depth of the studied section). This relates to the relatively modest geothermal gradient of $2.5^{\circ} \mathrm{C}$ per $100 \mathrm{~m}$. Analyses were performed on a Thermo Finnigan Trace Gas Chromatograph (GC) Ultra connected to a Thermo Finnigan DSQ mass spectrometer operated at $70 \mathrm{eV}$, with a range of $m / z$ 50-800 and a cycle time of three scans s ${ }^{-1}$. The temperature program and column conditions resemble that of Sinninghe Damsté et al. (2008). To quantify the GDGT abundances, a known amount of $\mathrm{C}_{46}$ GDGT standard was added (Huguet et al., 2006), after which the GDGT fractions were re-dissolved in hexane/propanol $(99: 1, v / v)$ and filtered over a $0.45 \mu \mathrm{m}$ mesh PTFE filter. The filtered GDGT fractions were analyzed using high-performance liquid chromatography - atmospheric pressure chemical ionization mass spectrometry (HPLC-APCI MS) according to the method described in Schouten et al. (2007a). Analyses were performed on an Agilent 1290 infinity series coupled to a 6130 single quadrupole MSD, equipped with autoinjection system and HP-Chemstation software. Separation was achieved on a Prevail Cyano column $(150 \mathrm{~mm} \times 2.1 \mathrm{~mm}$,
$3 \mu \mathrm{m}$; Alltech). GDGTs $(m / z$ 1018-1302) were detected using selective ion monitoring. For this method, it was exhibited that for samples with a high $\mathrm{TEX}_{86}$ value, a concentration of $0.1 \mathrm{ng}$ of injected GDGTs on the liquid chromatography (LC) column was still sufficient to yield credible TEX $_{86}$ values (Schouten et al., 2007a). The minimum GDGT concentration injected on the LC column per measurement in this study was $\sim 0.3 \mathrm{ng}$. TEX 86 index values were calculated after Schouten et al. (2002), and converted to absolute annual average sea surface temperatures (SSTs) using the TEX $\mathrm{H}$ Kim et al. (2010) modern core top calibration, which has a calibration error of $2.5^{\circ} \mathrm{C}$. Analytical reproducibility was generally better than $0.3^{\circ} \mathrm{C}$.

The branched and isoprenoid tetraether (BIT) index has been used to estimate the relative abundance of soil organic matter in marine sediments (Hopmans et al., 2004). The BIT index is based on the amount of predominantly soilderived branched GDGTs (brGDGTs) relative to the isoprenoid GDGT (iGDGT) crenarchaeol, which is chiefly derived from marine Thaumarchaeota. Application of the BIT index may be complicated by in situ production of brGDGTs in the marine water column and in marine sediments and the 
ubiquitous presence of crenarchaeol in soils. Nonetheless, many studies have shown that the BIT index is still a useful tracer for continental organic matter in marine environments (Schouten et al., 2013).

\subsection{Palynology}

In total, 51 samples were prepared for quantitative palynological analysis. In general, between 5 and $10 \mathrm{~g}$ (and for samples low in organic carbon, up to $\sim 20 \mathrm{~g}$ ) of freeze-dried sediment sample were crushed into pieces smaller than $5 \mathrm{~mm}$. Subsequently, a known amount of Lycopodium marker spores were added to allow for quantitative analysis. After reaction with $\sim 30 \%$ Hydrochloric acid $(\mathrm{HCl})$ and twice with $\sim 38 \%$ hydrofluoric acid (HF), to dissolve carbonates and silicates, respectively, ultrasonic separation was employed. Finally, samples were sieved through a $15 \mu \mathrm{m}$ nylon mesh. Residuals were mounted on slides for microscopic analysis. Approximately 250 dinocysts per sample were counted using a light microscope at $500 \times$ magnification. Taxonomy follows that of Fensome and Williams (2004). Pollen and spores were counted as one group, except for saccate gymnosperm pollen. All samples and slides are stored in the collection of the Laboratory of Palaeobotany and Palynology, Utrecht University, the Netherlands.

\section{Results}

\subsection{Total organic carbon}

Trends in and absolute values of TOC (Fig. 2) are generally in agreement with results reported by Hetzel et al. (2011), i.e., relatively high for black shales and low for marls and limestones. The background TOC content is $<0.3 \%$, somewhat higher than reported by Hetzel et al. (2011). Within the OAE2, four intervals with elevated TOC content are identified. The first interval is between 49 and $47.5 \mathrm{~m}$ and contains the first black shale at the onset of the CIE. A second organic-rich cluster is recognized at between $\sim 44$ and $42 \mathrm{mbs}$, with the maximum TOC content approaching $2 \%$. The third organic-rich interval is from 41 to $39.5 \mathrm{mbs}$, with a maximum TOC content just over $2.5 \%$. The last organicrich cluster ranges from 37.5 to $35.5 \mathrm{mbs}$, with a maximum TOC content just above $2 \%$. For the remainder of the record, only the youngest sample $(26.51 \mathrm{mbs})$ has an elevated TOC content (close to $1.5 \%$ ).

\subsection{Thermal maturity}

For two selected samples the hopane distribution was determined. $\mathrm{C}_{31} 17 \beta, 21 \beta(\mathrm{H})$ hopane was the dominant hopane. No $\alpha \beta$-hopanes were encountered, so the $(\beta \beta /(\beta \beta+\beta \alpha+$ $\alpha \alpha)$ ) of hopane biomarkers was 1 . This is in perfect agreement with Blumenberg and Wiese (2012), who reported that various types of hopanoids for the same core were dominated by the $17 \beta, 21 \beta(\mathrm{H})$ stereochemistry. This indicates that the thermal maturity of the sedimentary organic matter was sufficiently low for the application of TEX 86 paleothermometry (cf. Schouten et al., 2004).

Blumenberg and Wiese (2012) also reported much higher degrees of thermal maturity based upon isomerization ratios of biomarkers in hydropyrolysates generated from the kerogen. However, to obtain these pyrolysates, kerogens were heated up to $500^{\circ} \mathrm{C}$. It is well known that during such experiments the degree of isomerization of biomarkers alters towards a thermodynamic equilibrium mixture depending on time of the experiment and temperature applied (e.g., Koopmans et al., 1996). Accordingly, the data of Blumenberg and Wiese (2012) obtained from the hydropyrolysates are not relevant to assess the natural level of thermal maturity. Therefore, there is no conflict between the data of Blumenberg and Wiese (2012) and the data presented in this study.

\subsection{GDGT-based proxies}

Except for the sample at $41.45 \mathrm{mbs}$, all samples yielded quantifiable GDGT abundances, although of orders of magnitude different in concentration (Fig. 2c). Total GDGT concentrations are in the range of $0.13-43 \mu \mathrm{g} \mathrm{g}^{-1}$ organic carbon (OC). Crenarchaeol concentrations vary by 3 orders of magnitude, whereas brGDGT concentrations vary by $1-2$ orders of magnitude. High GDGT concentrations coincide with the organic carbon-rich black shales (Fig. $2 b$ and c), while low GDGT concentrations coincide with organic-poor sediments (Fig. 2b,c). Values for the BIT index range from 0.02 (indicating low relative abundances of soil-derived brGDGTs) to 0.56 , evidencing substantial soil-derived input of brGDGTs. The BIT index (Fig. 2d) is relatively high in the organic-poor intervals and generally low (i.e., $<0.10$ ) for the organic-rich black-shale intervals. Values for $\mathrm{TEX}_{86}$ fluctuate between 0.71 and 0.99 (Fig. 2e).

\subsection{Palynology}

Nine samples were barren of palynomorphs (Fig. 3c). For the remaining 42 samples, dinocyst concentrations range from $\sim 35$ to 15000 cysts per gram, and pollen and spores concentrations range from $10>$ to 5000 grains per gram, with highest concentrations in the organic-rich black shales (Fig. 3c).

Palynological assemblages are dominated by dinocysts, $\sim 85 \%$ on average (max. $>99 \%$ ). Summed pollen and spores, and hence the terrestrially derived fraction, comprises on average $\sim 15 \%$ of the assemblage (max. $\sim 40 \%$ ). The terrestrial over marine palynomorph ratio ( $\mathrm{T} / \mathrm{M}$ ratio) was calculated by dividing terrestrial palynomorphs (pollen and spores) by aquatic palynomorphs (dinocysts and acritarchs). In general $\mathrm{T} / \mathrm{M}$ values are elevated in the organic-rich intervals (Fig. 3h), while minima in the $\mathrm{T} / \mathrm{M}$ ratio correspond to organic-poor intervals. 


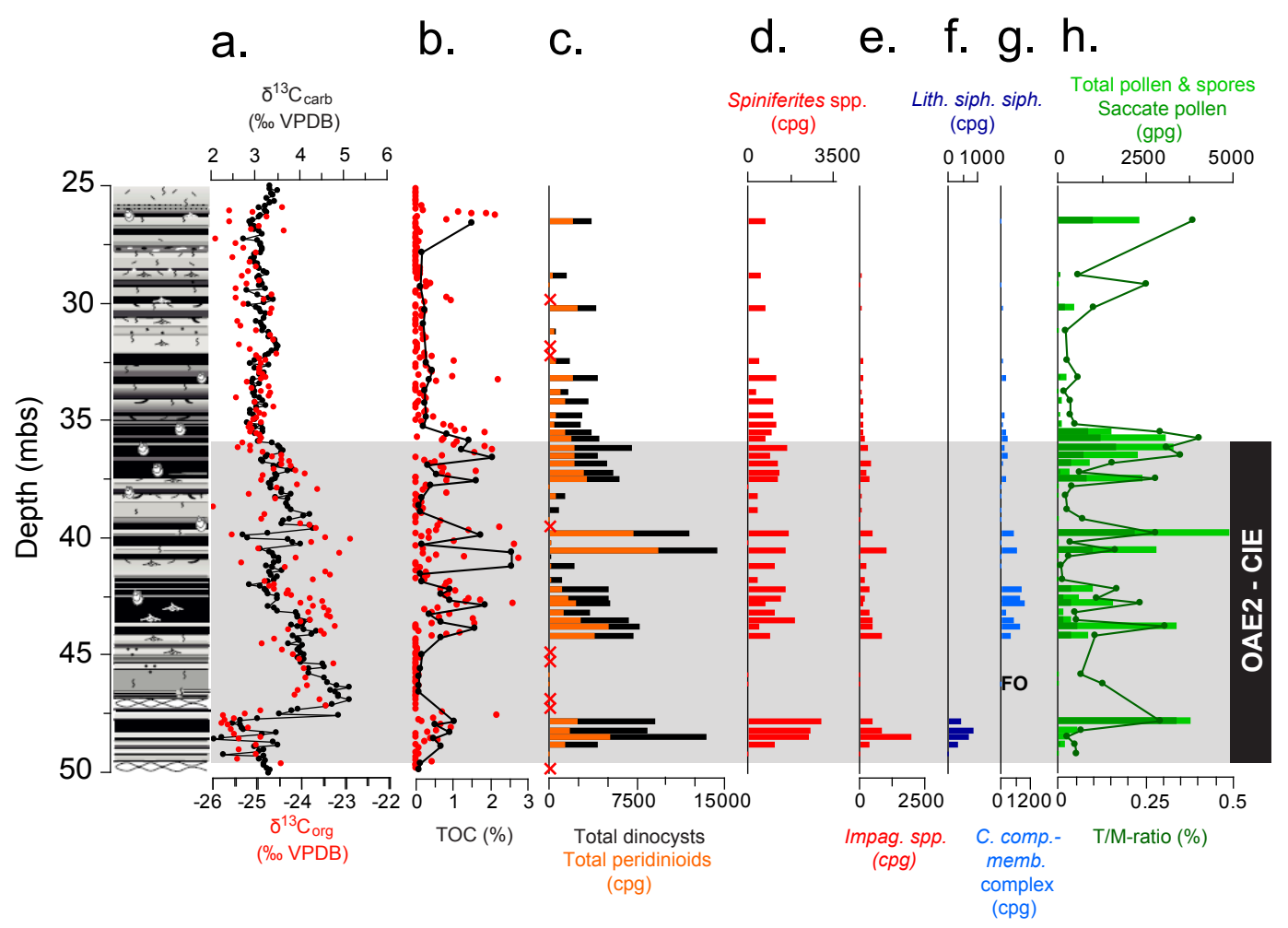

Figure 3. Geochemical and palynological results for the Cenomanian-Turonian transition of the Wunstorf core. Stratigraphy from Voigt et al. (2008). (a) $\delta^{13} \mathrm{C}_{\text {carb }}$ (Voigt et al., 2008) and $\delta^{13} \mathrm{C}_{\mathrm{org}}$ (du Vivier et al., 2014; red). (b) Total organic carbon (TOC: black, this study; red, Hetzel et al., 2011). (c) Total dinocyst concentrations (black) and total peridinioid cysts (orange) per gram sediment dry weight (cpg). (d) Dinocyst species Spiniferites spp. (cpg). (e) Dinocyst species Impagidinium spp. (cpg). (f) Dinocyst species Lithosphaeridium siphoniphorum siphoniphorum (cpg). (g) Dinocyst species Cyclonephelium compactum-C. membraniphorum complex (cpg). (h) Terrestrial vs. marine palynomorphs ( $\mathrm{T} / \mathrm{M}$ ratio) and total pollen and spores in grains per dry gram of sediment (gpg); saccate gymnosperm pollen in dark green. The grey zone indicates the OAE2 interval after Voigt et al. (2008).

Age-diagnostic dinocyst species include Lithosphaeridium siphoniphorum siphoniphorum, a marker species for the CTB interval in the northern European reference section at Eastbourne (Pearce et al., 2009). The last occurrence of $L$. siphoniphorum siphoniphorum is at $47.81 \mathrm{mbs}$ (Fig. 3f), confirming a date close to the end of the Cenomanian.

Dinocyst assemblages are dominated by multiple species of the Peridiniaceae family, i.e., Paleohystrichophora infusorioides, Subtilisphaera pontis-mariae, Eurydinium saxoniense, Isabelidinium spp. and Ginginodinium spp. Members of this family have repeatedly been shown to be derived of low-salinity tolerant dinoflagellates in Late Cretaceous and Paleogene successions and likely represent heterotrophic, euryhaline dinoflagellates (e.g., Harland, 1973; Sluijs and Brinkhuis, 2009; Powell et al., 1990; Lewis et al., 1990; Fig. 3c). Other quantitatively important taxa include Spiniferites spp. (Fig. 3d) and Impagidinium spp. (Fig. 3e), which are generally associated with outer shelf to oceanic environments (e.g., Wall et al., 1977; Harland, 1983; Brinkhuis, 1994). Commonly present are representatives of Odontochitina, Oligosphaeridium, Exochosphaeridium, Downiesphaeridium, Cyclonephelium, Lithos- phaeridium, Achomosphaera, and Florentinia spp., which are, like most encountered pollen and spores, typical for Late Cretaceous dinocyst shelf to bathyal assemblages (e.g., Dodsworth, 2004; Pearce et al., 2009; Peyrot et al., 2012).

\section{Discussion}

\subsection{SST reconstruction}

\subsubsection{Input of terrestrially derived GDGTs and post-depositional oxidation}

Small quantities of iGDGTs as used for determination of TEX $_{86}$ values are also produced in soils. High inputs of soil-derived iGDGTs, reflected by elevated BIT index val-

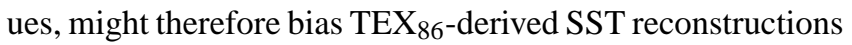
(Weijers et al., 2006). TEX 86 and BIT index values for the OAE2 record of the Wunstorf core exhibit a negative linear relationship $\left(\mathrm{R}^{2}\right.$ value of 0.43 ; Fig. 4 ), which may be the result of relatively high inputs of soil-derived iGDGTs, potentially affecting TEX $_{86}$ values. Previous work has rec- 


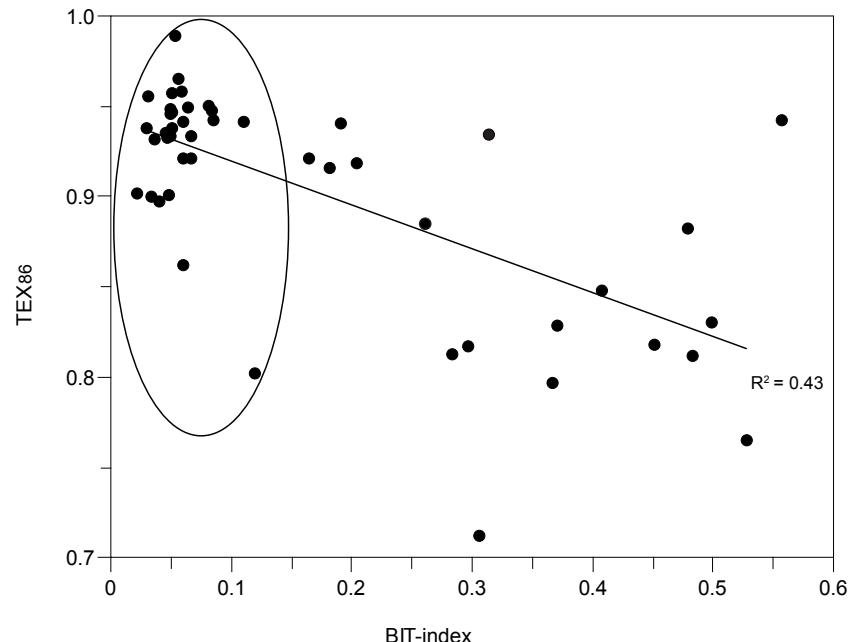

Figure 4. Cross plot of $\mathrm{TEX}_{86}$ against BIT index values.

ommended a cut-off value of the BIT index to exclude this effect from $\mathrm{TEX}_{86}$-based paleotemperature reconstructions (Weijers et al., 2006).

Low TOC sediments have high BIT index values and low TOC-normalized concentrations for brGDGTs and, to a larger extent, iGDGTs (Fig. 5). This is similar to results from TOC-rich turbidites that are affected by postdepositional oxidation (e.g., Huguet et al., 2008; Lengger et al., 2013). This is explained by preferential preservation of soil-derived brGDGTs over marine-derived iGDGTs upon post-depositional oxidation of the turbidites. For the Wunstorf section, the marls and limestones represent depositional phases during which the water column and pore waters of surface sediments contained relatively high concentrations of oxygen, as is evident from bioturbation, low TOC content (Fig. 2b) and low levels of redox-sensitive trace elements (Hetzel et al., 2011). Diagenetic effects caused by the oxidation of biomarkers in the water column and pore waters most likely played a substantial role in this depositional setting. Preferential preservation of brGDGTs is therefore likely responsible for the observed pattern in the BIT index. Although Lengger et al. (2013) did not find a bias in $\mathrm{TEX}_{86}$ values for sediments that suffered post-depositional oxidation, other studies have shown that there can be a considerable postdepositional oxidation effect on $\mathrm{TEX}_{86}$ values and thus the paleo-SST reconstructions derived from it (e.g., Huguet et al., 2009). The linear correlation between TEX ${ }_{86}$ and BIT index values for the analyzed sediments of the Wunstorf core is in line with the latter.

Based on the relationship between TOC and the BIT index (Fig. 5a) and the concentrations of the sum of the brGDGTs and crenarchaeol (Fig. 5b), we decided to remove reconstructed paleo-SST data with a BIT index $>0.15$. This changes the linear correlation between $\mathrm{TEX}_{86}$ and BIT index, suggesting that samples with a BIT index $>0.15$ are
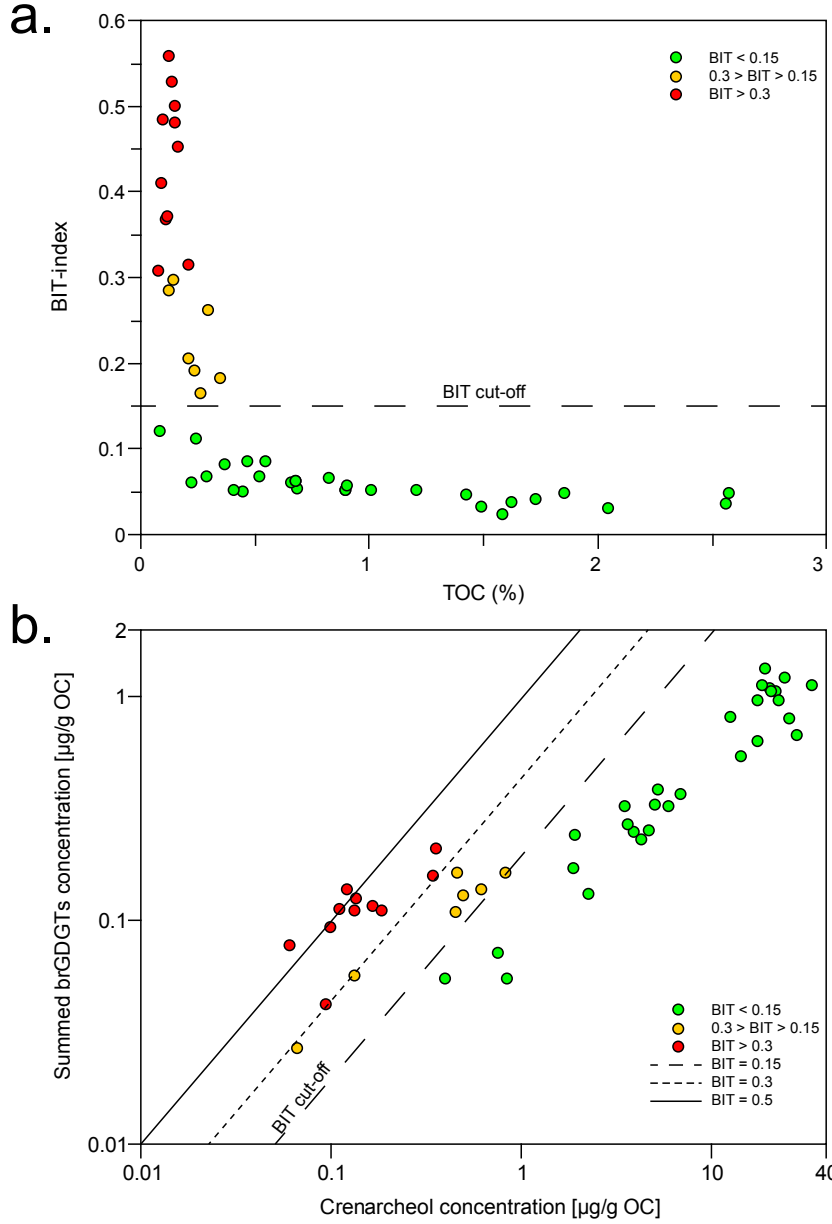

Figure 5. (a) Cross plot of summed brGDGTs ( $\mu \mathrm{gg}^{-1}$ OC) against crenarcheol ( $\mu \mathrm{g} \mathrm{g}^{-1} \mathrm{OC}$ ) on a logarithmic axis. (b) Cross plot of BIT index values against total organic carbon (TOC).

affected by post-depositional oxidation. This results in a data set in which samples with a BIT index value between 0.02 and 0.12 are considered for paleo-SST reconstructions, removing the impact of soil-derived iGDGTs on the paleo-SST reconstructions.

\subsubsection{Trends, stratigraphic correlation and absolute values}

Trends and values of the reconstructed SSTs at Wunstorf using the $\mathrm{TEX}_{86}^{\mathrm{H}}$ calibration of Kim et al. (2010; Fig. 6c) are similar to previous $\mathrm{TEX}_{86}$-based SST reconstructions for OAE2. Previously studied sites were located in the equatorial Atlantic (DSDP - Deep Sea Drilling Project, site 367 and ODP - ocean drilling program, site 1260; Forster et al., 2007) and the mid-latitudes (ODP site 1276 - Sinninghe Damsté et al., 2010; Bass River - van Helmond et al., 2014; Fig. 1). Potentially due to a lack of reliable $\mathrm{TEX}_{86}$ values at the onset of the OAE2 interval (Fig. 6b), the Wunstorf SST record does not capture the rapid increase in SST at the onset of OAE2, 


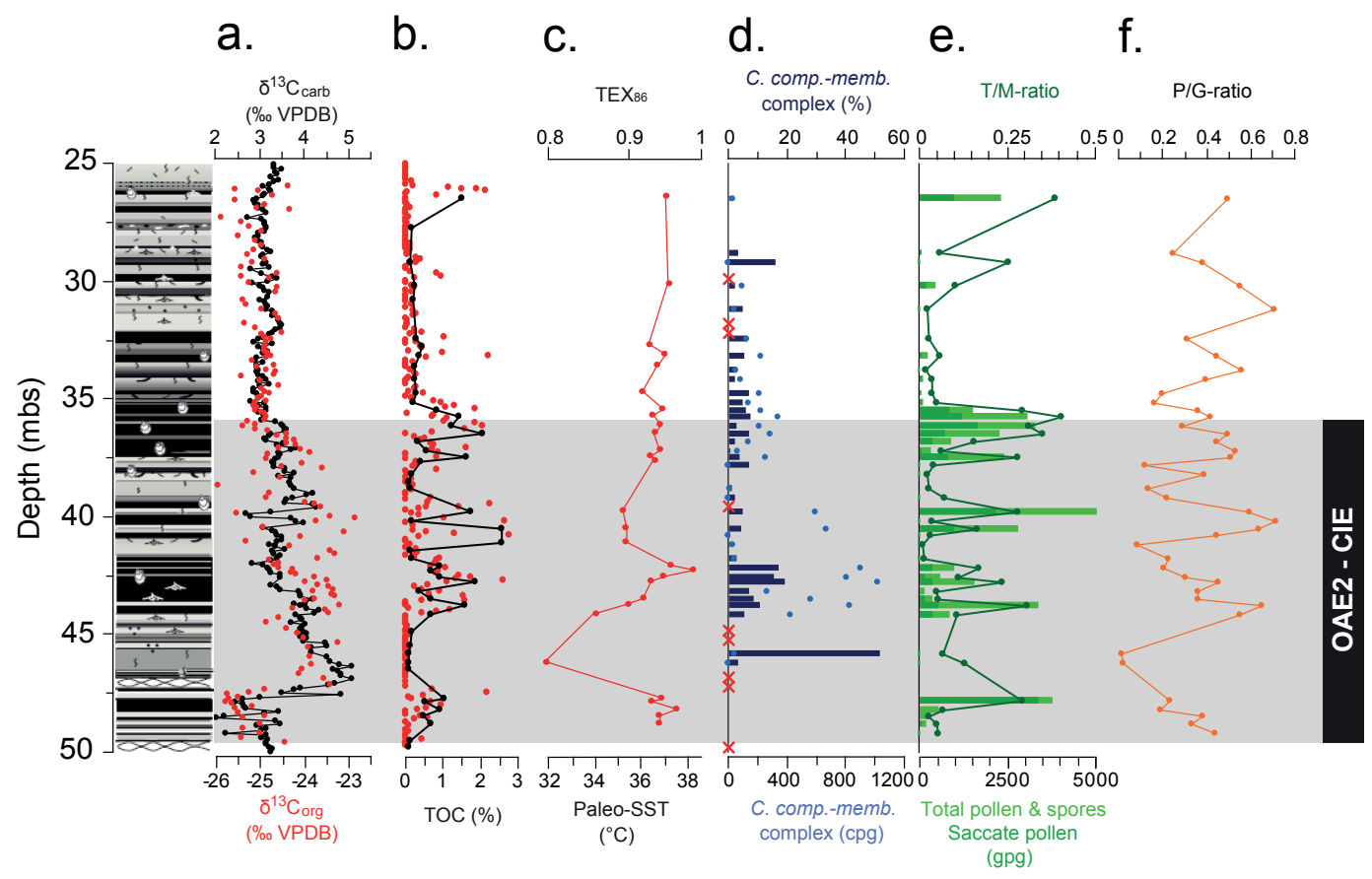

Figure 6. Geochemical and palynological results for the Cenomanian-Turonian transition of the Wunstorf core. Stratigraphy from Voigt et al. (2008). (a) $\delta^{13} \mathrm{C}_{\text {carb }}$ (Voigt et al., 2008) and $\delta^{13} \mathrm{C}_{\text {org }}$ (du Vivier et al., 2014; red). (b) Total organic carbon (TOC: black, this study; red, Hetzel et al., 2011). (c) $\mathrm{TEX}_{86}$ values and $\mathrm{TEX}_{86}^{\mathrm{H}}$-based SST reconstruction (Kim et al., 2010). (d) Relative abundance (\%) and absolute abundance in cysts per dry gram of sediment (cpg), of the dinocyst species Cyclonephelium compactum-C. membraniphorum complex, "X" represents barren samples. (e) Terrestrial vs. marine palynomorphs ( $\mathrm{T} / \mathrm{M}$ ratio) and total pollen and spores in grains per dry gram of sediment (gpg), saccate gymnosperm pollen in dark green. (f) Peridiniod vs. gonyaulacoid dinocysts (P/G ratio). The grey zone indicates the OAE2 interval after Voigt et al. (2008).

Table 1. Overview of the different sites for which $\mathrm{TEX}_{86}$-paleothermometry was applied over the OAE2 interval, and TEX 86 values and paleo-SST ranges and averages.

\begin{tabular}{llll}
\hline Site & $\begin{array}{l}\text { Estimated } \\
\text { paleo-latitude }\end{array}$ & $\begin{array}{l}\mathrm{TEX}_{86} \text { range } \\
\text { (average) }\end{array}$ & $\begin{array}{l}\text { Reconstructed paleo-SST } \\
\text { range (average) }\end{array}$ \\
\hline ODP Site $367^{\mathrm{b}}$ & $5^{\circ} \mathrm{N}$ & $0.84-0.95(0.90)$ & $33-37^{\circ} \mathrm{C}\left(36^{\circ} \mathrm{C}\right)$ \\
${\text { ODP Site } 1260^{\mathrm{b}}}^{\circ}$ & $0^{\circ}$ & $0.85-0.95(0.92)$ & $34-37^{\circ} \mathrm{C}\left(36^{\circ} \mathrm{C}\right)$ \\
ODP Site $1276^{\mathrm{c}}$ & $30^{\circ} \mathrm{N}$ & $0.74-0.96(0.90)$ & $30-37^{\circ} \mathrm{C}\left(36^{\circ} \mathrm{C}\right)$ \\
Bass River & $30^{\circ} \mathrm{N}$ & $0.84-0.95(0.91)$ & $33-37^{\circ} \mathrm{C}\left(36^{\circ} \mathrm{C}\right)$ \\
Wunstorf & $40^{\circ} \mathrm{N}$ & $0.80-0.99(0.93)$ & $32-38^{\circ} \mathrm{C}\left(36^{\circ} \mathrm{C}\right)$ \\
\hline
\end{tabular}

a Based on the $\mathrm{TEX}_{86}^{\mathrm{H}}$ calibration by Kim et al. (2010); ${ }^{\mathrm{b}}$ Forster et al. (2007); ${ }^{\mathrm{c}}$ Sinninghe Damsté et

al. (2010); ${ }^{\mathrm{d}}$ van Helmond et al. (2014).

previously attributed to a rise in atmospheric $\mathrm{CO}_{2}$ released by extensive volcanism (e.g., Forster et al., 2007). The Wunstorf SST record does show, despite being supported by predominantly one data point (resulting from the removal of samples with a BIT index $>0.15), \mathrm{a} \sim 5^{\circ} \mathrm{C}$ cooling pulse during the early stages of OAE2 (Fig. 6c). The six consecutive samples following our data point with the lowest SST values support a subsequent warming trend, following a colder phase however.
Based on its stratigraphic position within the early stages of the CIE, we attribute this cooling pulse to the Plenus Cold Event (PCE; Gale and Christensen, 1996). The PCE, an event first recognized as an incursion of boreal fauna in the shelf seas of NW Europe (e.g., Jefferies, 1962; Gale and Christensen, 1996; Voigt et al., 2004), represents a substantial cooling event based on $\mathrm{TEX}_{86}$-based paleo-SST records throughout the proto-North Atlantic basin (Forster et al., 2007; Sinninghe Damsté et al., 2010; van Helmond et al., 2014). At Wunstorf the data point with lowest SST corre- 
lates to a level above the Plenus bank, located at 47.30 $46.85 \mathrm{mbs}$ (Voigt et al., 2008) after the maximum in the CIE. The lack of reliable SST data for the interval between 47.74 and 46.21 mbs complicates precise determination of the onset of the PCE at Wunstorf however. In three more "complete", previously published TEX 86 -based paleoSST records across the PCE, i.e., ODP site 1260 (Forster et al., 2007), ODP site 1276 (Sinninghe Damsté et al., 2010) and Bass River (van Helmond et al., 2014), the cooling in TEX $_{86}$-based SSTs starts before the first maximum in the CIE, prior to the occurrence of boreal fauna in the shelf seas of NW Europe (Gale and Christensen, 1996), suggesting that faunal migrations lagged the cooling event as reconstructed by $\mathrm{TEX}_{86}$. Therefore precise correlations of the PCE between sites remains challenging. The identification of the PCE at Wunstorf, alongside the previous identifications of the PCE throughout the proto-North Atlantic basin, suggest that the PCE was a hemisphere-wide and perhaps even a global event. This supports the hypothesis that enhanced global carbon burial temporary suppressed atmospheric $\mathrm{CO}_{2}$ levels during OAE2 (Arthur et al., 1988; Sinninghe Damsté et al., 2010). The PCE is related to changes in ocean circulation, recorded by the incursion of a northerly sourced water mass as derived from a negative neodymium isotope excursion in the English Chalk at Eastbourne (Zheng et al., 2013) and a trace metal anomaly in the Western Interior Seaway (Eldrett et al., 2014). This northerly sourced water mass may have been instrumental for the dispersion of boreal fauna in the shelf seas of NW Europe, in line with the observed differences in timing between TEX $_{86}$-based cooling in SSTs and the occurrence of boreal fauna. Interestingly, the interval of the PCE marks the occurrence of the Cyclonephelium compactum-C. membraniphorum complex (C. comp.-memb. cplx.) within the OAE2 interval in the Wunstorf core (Fig. 6c, d). This is in accordance with previous records from the Bass River section (van Helmond et al., 2014) and the Shell Iona-1 core (Eldrett et al., 2014). Although the biogeographic distribution of this complex is still partly unclear, this suggests that the introduction of C. comp.-memb. cplx. at mid-latitude sites in both northern Europe and the east coast of North America was quasi-instantaneous and linked to the PCE.

No significant difference in the reconstructed SSTs is recorded between the black shales and the more TOC-poor marls and limestones. This suggests that the cyclic deposition of black shales during OAE2 in the LSB was not primarily driven by changes in SST.

Average SSTs for the OAE2 interval at Wunstorf are higher than at Bass River (New Jersey shelf), DSDP site 367 (Cape Verde Basin), ODP site 1260 (Demerara Rise), and site 1276 (North Atlantic; Table 1), which may perhaps be an artefact of the low resolution achieved for the Plenus Cold Event at Wunstorf. Reconstructions of absolute temperatures based on $\mathrm{TEX}_{86}$ at values significantly exceeding the modern calibration may yield significant errors, since the modern core-top calibration is limited to $30^{\circ} \mathrm{C}$ (Kim et al., 2010).
Therefore, SSTs exceeding this value will always be based on extrapolation, although mesocosm studies have revealed that $\mathrm{TEX}_{86}$ also shows a positive response with increasing temperatures in the $30-40{ }^{\circ} \mathrm{C}$ range (Schouten et al., 2007b). Furthermore the logarithmic TEX ${ }_{86}^{\mathrm{H}}$ index (Kim et al., 2010), used in this study, has a calibration maximum of $38.6^{\circ} \mathrm{C}$, i.e., when $\mathrm{TEX}_{86}=1$, the reconstructed SST is $38.6^{\circ} \mathrm{C}$. SSTs reconstructions for samples with a $\mathrm{TEX}_{86}$ value $>0.9$ may therefore be relatively conservative. Nonetheless, the warm and relatively stable background SSTs for Wunstorf $\left(\sim 37^{\circ} \mathrm{C}\right)$ suggest that SSTs on the European shelf were exceptionally high and supports the notion that thermal gradients were substantially reduced during the Late Cretaceous greenhouse world (e.g., Baron, 1983; Huber et al., 1995).

\subsection{Hydrology}

Although pollen rank among the most resistant groups of palynomorphs (Traverse, 1994), there is evidence that pollen grains degrade relatively rapidly $(<10 \mathrm{kyr})$ in the presence of diffusively introduced oxygen (e.g., Keil et al., 1994). This may perhaps explain why absolute pollen and spores concentrations are higher in the black shales, deposited under anoxic conditions. This contrasts with the organic-poor marls and limestones deposited during phases in which pore waters of surface sediments contained relatively high concentrations of oxygen, explaining the low absolute pollen and spores concentrations.

Among modern dinoflagellate cysts, members of the family Protoperidiniaceae are most sensitive to oxidation, and thus may potentially be affected by differential preservation (e.g., Zonneveld, et al., 1997, 2001; Versteegh and Zonneveld, 2002). No consensus exists in the field whether this differential preservation is imprinted in the sedimentary record (e.g., Reichart and Brinkhuis, 2003). At present, there is no published information that suggests that the selective preservation of dinocysts plays a role in assemblages described from the Cretaceous. If there were one dinocyst taxon potentially prone to be selectively degraded in the assemblages we record, it would be the thin-walled taxon Paleohystrichophora infusorioides, which also belongs to the peridinioids. Well-preserved representatives of $P$. hystrichophora are, however, commonly present in the organic-poor marls and limestones.

Pollen and spores are transported to the marine environment by a wide range of processes, with river discharge and wind being the most important factors (e.g., Traverse and Ginsburg, 1966; Thomson, 1986; Feinsinger and Busby, 1987). The saccate gymnosperm pollen (bisaccates) in particular may be transported by eolian pathways (e.g., Heusser, 1988). Palynological assemblages at Wunstorf are a mixture of saccate gymnosperm pollen and non-saccate gymnosperm pollen and spores, suggesting a mixture of eolian and fluvial input of pollen and spores. However, most of the analyzed samples contain relatively low amounts of saccate 
gymnosperm pollen (Fig. 6e; Prauss, 2006), suggesting that a substantial amount of the pollen and spores encountered at Wunstorf were transported to the marine realm by fluvial processes. The relatively high amounts of pollen and spores with respect to marine palynomorphs ( $\mathrm{T} / \mathrm{M}$ ratio; Fig. 6e) in the black shales at Wunstorf are therefore interpreted to represent phases of enhanced run-off. This was previously also shown for other Cretaceous oceanic anoxic events (e.g., Herrle et al., 2003). Enhanced run-off most likely resulted from increased (seasonal) precipitation over northern and mid-European landmasses, assuming that these yielded significant vegetation cover. Regarding the distance to the coring site, non-saccate pollen and spores most likely originated from the Bohemian Massif (e.g., Falcon-Lang et al., 2001; Herman et al., 2002), which is in accordance with the prevailing paleo-wind directions (Hay and Floegel, 2012). Enhanced (seasonal) influx of fresh, low-density surface waters could well have stratified the water column, leading to low oxygen levels in bottom waters. This is also indicated by high abundances of bacterivorous ciliates (Blumenberg and Wiese, 2012), which graze on the interfaces of stratified water bodies (Sinninghe Damsté et al., 1995), supporting the presence of a chemocline in the water column. A persistent stratification of the water column ultimately leads to bottom water anoxia and the formation of black shales in the deeper parts of the LSB. The coupling of the rhythmical occurrence of the black shale layers to the precession cycle (Voigt et al., 2008) suggests that changes in the hydrological cycle were controlled by Earth's orbital parameters.

\subsection{Marine productivity}

High abundances of dinocysts and organic matter in general may result from both enhanced marine primary productivity and an improved preservation potential for organic matter during black shale deposition. In modern oceans, most peridinioid dinocysts are produced by heterotrophic dinoflagellates, while most gonyaulacoid dinocysts are derived from autotrophic taxa (Lewis et al., 1990). As a consequence, the ratio between peridinioids and gonyaulacoids ( $\mathrm{P} / \mathrm{G}$ ratio) has been employed widely as a proxy for paleoproductivity (Sluijs et al., 2005). In the Wunstorf OAE2 section, the P / G ratio reaches maximum values within the different black shale couplets, implying that productivity was elevated during their deposition (Fig. 6f). Furthermore the peridinioids encountered at Wunstorf belong to the Peridiniaceae family, which has been shown to be low-salinity tolerant (e.g., Harland, 1973; Sluijs and Brinkhuis, 2009). Together, this suggests that during seasons of high precipitation and runoff that introduced nutrients, a low-salinity, high-productivity surface layer existed in the Lower Saxony Basin. This hypothesis is supported by assemblages of calcareous nannofossils, showing a shift from a generally oligotrophic ecosystem to more mesotrophic or even eutrophic conditions during black shale deposition (Linnert et al., 2010).
Enhanced marine primary productivity likely contributed to the establishment of bottom water anoxia by increasing the flux of organic matter to the seafloor, depleting bottom water oxygen concentrations upon decay.

\section{Conclusions}

Despite differences in the preservation of organic matter throughout the OAE2 interval at Wunstorf, the general trend in reconstructed SSTs, including the cooling phase associated with the Plenus Cold Event, is consistent with the results of previous studies that focused on the proto-North Atlantic. Hence, the SST trend recorded at Wunstorf and the other sites was of at least hemispheric significance. Reconstructed SSTs do not substantially differ between black shales and less organic-rich deposits. This implies that although higher temperatures must have had an effect on the solubility of oxygen in seawater, surface temperature was not the critical factor for the cyclic deposition of organic matter. Absolute SSTs for the Wunstorf OAE2 section show little or no difference in comparison with SST reconstructions for sites located at lower latitudes, which were evaluated using the same proxy and the same methodology. This confirms that thermal gradients were much reduced during the Late Cretaceous (Barron, 1983; Huber et al., 1995).

The dinocyst Cyclonephelium compactum-C. membraniphorum complex, previously linked to the Plenus Cold Event (van Helmond et al., 2014), was encountered at the respective level at Wunstorf, suggesting that its occurrence is indeed linked to this cooling. Its continued presence in the remainder of the record suggests, however, that other paleoenvironmental factors were also critical in controlling its distribution.

A combination of continental configuration and extensive volcanism, intensifying greenhouse conditions around the CTB, resulted in an epicontinental shelf sea prone to black shale deposition as a consequence of precession-driven climate change at Wunstorf, (Voigt et al., 2008). We conclude, based on relatively high numbers of terrestrially derived pollen and spores and freshwater-tolerating dinocysts in the black shale intervals, that precession was driving variations in the hydrological cycle. This caused (seasonal) freshwater stratification of the water column and likely enhanced primary production, ultimately culminating in bottom water anoxia and black shale formation. An orbitally controlled hydrological cycle may have been a critical factor for other cyclic OAE2 sites located in the proto-Atlantic and Western Interior Seaway at similar latitudes as well.

\section{The Supplement related to this article is available online at doi:10.5194/cp-11-495-2015-supplement.}


Acknowledgements. The Wunstorf Coring Scientific Drilling Party is thanked for providing the chance to work on their exceptionally well-recovered core. We thank Itzel Ruvalcaba Baroni and Walter Hale for sampling support, and Dominika Kasjaniuk, Arnold van Dijk, Natasja Welters, Jan van Tongeren (Utrecht University), and Anchelique Mets (NIOZ) for analytical assistance and sample preparation. Andrew Gale and David Naafs are thanked for their constructive reviews. We acknowledge NWO for funding the purchase of the HPLC-MS (grant no. 834.11.006) used for the GDGT analysis presented in this study. This research was supported by the Focus and Massa project of Utrecht University granted to Henk Brinkhuis and Caroline Slomp, and additional financial support by Statoil. The European Research Council (ERC) under the European Union Seventh Framework Program provided funding for this work by ERC Starting Grant no. 259627 to Appy Sluijs.

Edited by: A. Haywood

\section{References}

Arthur, M. A., Dean, W. E., and Pratt, L. M.: Geochemical and climatic effects of increased marine organic carbon burial at the Cenomanian/Turonian boundary, Nature, 335, 714-717, 1988.

Barclay, R. S., McElwain, J. C., and Sageman, B. B.: Carbon sequestration activated by avolcanic $\mathrm{CO}_{2}$ pulse during Oceanic Anoxic Event 2, Nat. Geosci., 3, 205-208, 2010.

Barron, E. J.: A warm, equable Cretaceous: the nature of the problem, Earth-Sci. Rev., 19, 305-338, 1983.

Bice, K. L., Birgel, D., Meyers, P. A., Dahl, K. A., Hinrichs, K.-U., and Norris, R. D.: A multiple proxy and model study of the Cretaceous upper ocean temperatures and atmospheric $\mathrm{CO}_{2}$ concentrations, Paleoceanography, 21, PA2002, doi:10.1029/2005PA001203, 2006.

Blättler, C. L., Jenkyns, H. C., Reynard, L. M., and Henderson, G. M.: Significant increases in global weathering during Oceanic Anoxic Events 1a and 2 indicated by calcium isotopes, Earth Planet. Sci. Lett., 309, 77-88,2011.

Blumenberg, M. and Wiese, F.: Imbalanced nutrients as triggers for black shale formation in a shallow shelf setting during the OAE 2 (Wunstorf, Germany), Biogeosciences, 9, 4139-4153, doi:10.5194/bg-9-4139-2012, 2012.

Brinkhuis, H.: Late Eocene to Early Oligocene dinoflagellate cysts from the Priabonian type-area (northeast Italy): biostratigraphy and palaeoenvironmental interpretation, Palaeogeogr. Palaeocl., 107, 121-163, 1994.

Creaney, S. and Passey, Q. R.: Recurring Patterns of Total Organic Carbon and Source Rock Quality within a Sequence Stratigraphic Framework, AAPG Bull., 77, 386-401, 1993.

Dodsworth, P.: The palynology of the Cenomanian-Turonian (Cretaceous) boundary succession at Aksudere in Crimea, Ukraine, Palynology, 28, 129-141, 2004.

Du Vivier, A. D. C., Selby, D., Sageman, B. B., Jarvis, I., Gröcke, D. R., and Voigt, S.: Marine ${ }^{187}$ Os / ${ }^{188}$ Os isotope stratigraphy reveals the interaction of volcanism and ocean circulation during Oceanic Anoxic Event 2, Earth Planet. Sc. Lett., 389, 23-33, 2014.
Eldrett, J. S., Minisini, D., and Bergman, S. C.: Decoupling of the carbon cycle during Ocean Anoxic Event 2, Geology, 42, 567570, 2014.

Erbacher, J., Thurow, J., and Littke, R.: Evolution patterns of radiolarian and organic matter variations: A new approach to identify sea-level changes in mid-Cretaceous pelagic environments, $\mathrm{Ge}-$ ology, 6, 499-502, 1996.

Erbacher, J., Mutterlose, J., Wilmsen, M., Wonik, T., and Party, W. D. S.: The Wunstorf Drilling Project: Coring a global stratigraphic reference section of the Oceanic Anoxic Event 2, Scien. Drill., 4, 19-21, 2007.

Ernst, G., Wood, C. J., and Hilbrecht, H.: The CenomanianTuronian boundary problem in NW-Germany with comments on the north-south correlation to the Regensburg area, Bull. Geol. Soc. Den., 33, 103-113, 1984.

Falcon-Lang, H. J., Kvacek, J., and Ulicný, D.: Fire-prone plant communities and palaeoclimate of a Late Cretaceous fluvial to estuarine environment, Pecínov quarry, Czech Republic, Geol. Mag., 138, 563-576, 2001.

Feinsinger, P. and Busby, W. H.: Pollen carryover: experimental comparisons between morphs of Palicourea lasiorrachis (Rubiaceae), a distylous, bird-pollinated, tropical treelet, Oecologia, 73, 231-235, 1987

Fensome, R. A., and Williams, G. L.: The Lentin and Williams Index of Fossil Dinoflagellates, 2004 Edition, Am. Assoc. Stratigr. Palynol. Contribut. Ser., 42, 909 pp., 2004.

Forster, A., Schouten, S., Moriya, K., Wilson, P. A., and Sinninghe Damsté, J. S.: Tropical warming and intermittent cooling during the Cenomanian/Turonian Oceanic Anoxic Event (OAE 2): Sea surface temperature records from the equatorial Atlantic, Paleoceanography, 22, PA1219, doi:10.1029/2006PA001349, 2007.

Forster, A., Kuypers, M. M. M., Turgeon, S. C., Brumsack, H.J., Petrizzo, M. R., and Sinninghe Damsté, J. S.: The Cenomanian/Turonian oceanic anoxic event in the South Atlantic: new insights from a geochemical study of DSDP Site 530A, Palaeogeogr. Palaeocl., 267, 256-283, 2008.

Gale, A. S. and Christensen, W. K.: Occurrence of the belemnite Actinocamax plenus in the Cenomanian of SE France and its significance, Bull. Geol. Soc. Den., 43, 68-77, 1996.

Hancock, J. M. and Kauffman, E. G.:The great transgressions of the Late Cretaceous, J. Geol. Soc. London, 136, 175-186, 1979.

Harland, R.: Dinoflagellate cysts and acritarchs from the Bearpaw Formation (Upper Campanian) of southern Alberta, Canada, Palaeontology, 16, 665-706, 1973.

Harland, R.: Distribution maps of recent dinoflagellate cysts in bottom sediments from the North Atlantic Ocean and adjacent seas, Palaeontology, 26, 321-387, 1983.

Hay, W. W. and Flögel, S.: New thoughts about the Cretaceous climate and oceans, Earth-Sci. Rev., 115, 262-272, 2012.

Herman, A. B., Spicer, R. A., and Kvaček, J.: Late Cretaceous climate of Eurasia and Alaska: a quantitative palaeobotanical approach, in: Aspect of Cretaceous Stratigraphy and Palaeobiogeography, edited by: Wagreich, M., Österrische Akademie der Wissenschaften, 15, 93-108, 2002.

Herrle, J. O., Pross, J., Friedrich, O., Kößler, P., and Hemleben, C.: Forcing mechanisms for mid-Cretaceous black shale formation: evidence from the Upper Aptian and Lower Albian of the Vocontian Basin (SE France), Palaeogeogr. Palaeocl., 190, 399-426, 2003. 
Hetzel, A., März, C., Vogt, C., and Brumsack, H.-J.: Geochemical environment of Cenomanian-Turonian black shale deposition at Wunstorf (northern Germany), Cretaceous Res., 32, 480-494, 2011.

Heusser, L. E.: Pollen distribution in marine sediments on the continental margin off northern California, Mar. Geol., 80,131-147, 1988.

Hopmans, E. C., Weijers, J. W. H., Schefuß, E., Herfort, L., Sinninghe Damsté, J. S., and Schouten, S.: A novel proxy for terrestrial organic matter in sediments based on branched and isoprenoid tetraether lipids, Earth Planet. Sc. Lett., 224, 107-116, 2004.

Huber, B. T., Hodell, D. A., and Hamilton, C. P.: Middle-Late Cretaceous climate of the southern high latitudes: stable isotopic evidence for minimal equator-to-pole thermal gradients, Geol. Soc. Am. Bull., 107, 1164-1191, 1995.

Huguet, C., Hopmans, E. C., Febo-Ayala, W., Thompson, D. H., Sinninghe Damsté, J. S., and Schouten, S.: An improved method to determine the absolute abundance of glycerol di biphytanyl glycerol tetraether lipids, Org. Geochem., 37, 1036-1041, 2006.

Huguet, C., de Lange, G. J., Middelburg, J. J., Sinninghe Damsté, J. S., and Schouten, S.: Selective preservation of soil organic matter in oxidized marine sediments (Madeira Abyssal Plain), Geochim. Cosmochim. Ac., 72, 6061-6068, 2008.

Huguet, C., Kim, J.-H., de Lange, G.J., Sinninghe Damsté, J. S., and Schouten, S.: Effects of long-term oxic degradation on the $\mathrm{U}_{37}^{K^{\prime}}$, TEX $_{86}$ and BIT organic proxies, Org. Geochem., 40, 1188-1194, 2009.

Jarvis, I., Lignum, J. S., Gröcke, D. R., Jenkyns, H. C., and Pearce, M. A.: Black shale deposition, atmospheric $\mathrm{CO}_{2}$ drawdown, and cooling during the Cenomanian-Turonian Oceanic Anoxic Event, Paleoceanography 26, PA3201, doi:10.1029/2010PA002081, 2011.

Jefferies, R. P. S.: The palaeoecology of the Actinocamax plenus subzone(lowest Turonian) in the Anglo-Paris Basin, Palaeontology, 4, 609-647, 1962.

Jenkyns, H. C.: Geochemistry of oceanic anoxic events, Geochem. Geophy. Geosy., 11, Q03004, doi:10.1029/2009GC002788, 2010.

Junium, C. K. and Arthur, M. A.: Nitrogen cycling during the Cretaceous, Cenomanian-Turonian Oceanic Anoxic Event II. Geochem. Geophy. Geosy., 8, Q03002, doi:10.1029/2006GC001328, 2007.

Keil, R. G., Hu, E. S., Tsamakis, E. C., and Hedges, J. I.: Pollen in marine sediments as an indicator of oxidation of organic matter, Nature, 369, 639-641, 1994.

Kerr, A. C.: Oceanic plateau formation: a cause of mass extinction and black shale deposition around the Cenomanian-Turonian boundary?, J. Geol. Soc. London, 155, 619-626, 1998.

Kim, J.-H., van der Meer, J., Schouten, S., Helmke, P., Willmott, V., Sangiorgi, F.,Koç, N., Hopmans, E. C., and Sinninghe Damsté, J. S.: New indices and calibrations derived from the distribution of crenarchaeal isoprenoid tetraether lipids: Implications for past sea surface temperature reconstructions, Geochim. Cosmochim. Ac., 74, 4639-4654, 2010.

Koopmans, M. P., De Leeuw, J. W., Lewan, M. D., and Sinninghe Damsté, J. S.: Impact of dia-and catagenesis on sulphur and oxygen sequestration of biomarkers as revealed by artificial matu- ration of an immature sedimentary rock, Organ. Geochem., 25, 391-426, 1996.

Kuroda, J., Ogawa, N., Tanimizu, M., Coffin, M., Tokuyama, H., Kitazato, H., and Ohkouchi, N.: Contemporaneous massive subaerial volcanism and late cretaceous Oceanic Anoxic Event 2, Earth Planet. Sc. Lett., 256, 211-223, 2007.

Kuypers, M. M. M., Lourens, L. J., Rijpstra, W. I. C., Pancost, R. D., Nijenhuis, I. A., and Sinninghe Damsté, J. S.: Orbital forcing of organic carbon burial in the proto-North Atlantic during oceanic anoxic event 2, Earth Planet. Sc. Lett. 228, 465-482, 2004a.

Kuypers, M. M. M., van Breugel, Y., Schouten, S., Erba, E., and Sinninghe Damsté, J. S.: $\mathrm{N}_{2}$-fixing cyanobacteria supplied nutrient $\mathrm{N}$ for Cretaceous oceanic anoxic events, Geology, 32, 853856. 2004b.

Lengger, S. K., Kraaij, M., Tjallingii, R., Baas, M., Stuut, J. B., Hopmans, E. C., Sinninghe Damsté, J. S., and Schouten, S.: Differential degradation of intact polar and core glycerol dialkyl glycerol tetraether lipids upon post-depositional oxidation, Org. Geochem., 65, 83-93, 2013.

Lewis, J., Dodge J. D., and Powell, J.: Quaternary dinoflagllate cysts from the upwelling system offshore Peru, Hole 686B, ODP Leg 112, in: Proceedings of the Ocean Drilling Program, Scientific Results, edited by: Suess, E., von Huene, R., Emeis, K.-C., Bourgois, J., del C. Cruzado Castaheda, J., De Wever, P., Eglinton, G., Garrison, R., Greenberg, M., Herrera Paz, E., Hill, P., Ibaraki, M., Kastner, M., Kemp, A. E. S., Kvenvolden, K., Langridge, R., Lindsley-Griffin, N., Marsters, J., Martini, E., McCabe, R., Ocola, L., Resig, J., Wilfredo Sanchez Fernandez, A., Schrader, H. J., Thornburg, T., Wefer, G., and Yamano, M., 112, 323-328, 1990.

Linnert, C., Mutterlose, J., and Erbacher, J.: Calcareous nannofossils of the Cenomanian/Turonian boundary interval from the Boreal Realm (Wunstorf, northern Germany), Mar. Micropaleontol., 74, 38-58, 2010.

Marshall, K. L. and Batten, D. J.: Dinoflagellate cyst associations in Cenomanian-Turonian "black shale" sequences of northern Europe, Rev. Palaeobot. Palyno., 54, 85-103, 1988.

Meyers, S. R., Sageman, B. B., and Arthur, M. A.: Obliquity forcing and the amplification of high-latitude climate processes during Oceanic Anoxic Event 2, Paleoceanography, 27, PA3212, doi:10.1029/2012PA002286, 2012.

Miller, K. G., Kominz, M. A., Browning, J. V., Wright, J. D., Mountain, G. S., Katz, M. E., Sugarman, P. J., Carter, B. S., ChristieBlick, N., and Pekar, S. F.: The Phanerozoic record of global sea-level change, Science, 310, 1293-1298, 2005.

Mort, H. P., Adatte, T., Föllmi, K. B., Keller, G., Steinmann, P., Matera, V., Berner, Z., and Stuben, D.: Phosphorus and the roles of productivity and nutrient recycling during oceanic anoxic event 2, Geology, 35, 483-486, 2007.

Pearce, M. A., Jarvis, I., and Tocher, B. A.: The CenomanianTuronian boundary event, OAE 2 and palaeoenvironmental change in epicontinental seas: new insights from the dinocyst and geochemical records, Palaeogeograph. Palaeocl., 280, 207-234, 2009.

Peyrot, D., Barroso-Barcenilla, F., and Feist-Burkhardt, S.: Palaeoenvironmental controls on late Cenomanian-early Turonian dinoflagellate cyst assemblages from Condemios (Central Spain), Rev. Palaeobot. Palyno., 180, 25-40, 2012. 
Pogge von Strandmann, P. A. E., Jenkyns, H. C., and Woodfine, R. G.: Lithium isotope evidence for enhanced weathering during Oceanic AnoxicEvent 2, Nat. Geosci., 6, 668-672, 2013.

Poulsen, J. C., Barron, E. J., Arthur, A., and Peterson, H.: Response of the mid-Cretaceous global oceanic circulation to tectonic and $\mathrm{CO}_{2}$ forcings, Paleoceanography, 16, 576-592, 2001.

Powell, A. J., Dodge, J. D., and Lewis, J.: Late Neogene to Pleistocene palynological facies of the Peruvian continental margin upwelling, Leg 112, in: Proceedings of the Ocean Drilling Program, Scientific Results, edited by: Suess, E., von Huene, R., Emeis, K.-C., Bourgois, J., del C. Cruzado Castaheda, J., De Wever, P., Eglinton, G., Garrison, R., Greenberg, M., Herrera Paz, E., Hill, P., Ibaraki, M., Kastner, M., Kemp, A. E. S., Kvenvolden, K., Langridge, R., Lindsley-Griffin, N., Marsters, J., Martini, E., McCabe, R., Ocola, L., Resig, J., Wilfredo Sanchez Fernandez, A., Schrader, H. J., Thornburg, T., Wefer, G., and Yamano, M., 112, 297-321, 1990.

Prauss, M. L.: The Cenomanian-Turonian Boundary Event (CTBE) at Wunstorf, north-west Germany, as reflected by marine palynology, Cretaceous Res., 27, 872-886, 2006.

Reichart, G. J. and Brinkhuis, H.: Late Quaternary Protoperidinium cysts as indicators of paleoproductivity in the northern Arabian Sea, Mar. Micropaleontol., 937, 1-13, 2003.

Schlanger, S. O. and Jenkyns, H. C.: Cretaceous oceanic anoxic events: Causes and consequences, Geol. Mijnbouw, 55, 179-184, 1976.

Schouten, S., Hopmans, E. C., Schefuss, E., and Sinninghe Damsté, J. S.: Distributional variations in marine crenarchaeotal membrane lipids: a new tool for reconstructing ancient sea water temperatures?, Earth Planet. Sci. Lett., 204, 265-274, 2002.

Schouten, S., Hopmans, E. C., Forster, A., van Breugel, Y., Kuypers, M. M. M., and Sinninghe Damsté, J. S.: Extremely high seasurface temperatures at low latitudes during the middle Cretaceous as revealed by archaeal membrane lipids, Geology, 31, 1069-1072, 2003.

Schouten, S., Hopmans, E. C., and Sinninghe Damsté, J. S.: The effect of maturity anddepositional redox conditions on archaeal tetraether lipid palaeothermometry, Org. Geochem. 35, 567-571, 2004.

Schouten, S., Huguet, C., Hopmans, E. C., Kienhuis, M. V. M., and Sinninghe Damsté: J. S.: Improved analytical methodology for $\mathrm{TEX}_{86}$ paleothermometry by high performance liquid chromatography/atmospheric pressure chemical ionization-mass spectrometry, Anal. Chem., 79, 2940-2944, 2007a.

Schouten, S., Forster, A., Panoto, F. E., and Sinninghe Damsté, J. S.: Towards calibration of the TEX86 palaeothermometer for tropical sea surface temperatures in ancient greenhouse worlds, Org. Geochem., 38, 1537-1546, 2007b.

Schouten, S., Hopmans, E. C., and Sinninghe Damsté, J. S.: The organic geochemistry of glycerol dialkyl glycerol tetraether lipids: a review, Org. Geochem., 54, 19-61, 2013.

Sinninghe Damsté, J. S., Kenig, F., Koopmans, M. P., Köster, J., Schouten, S., Hayes, J. M., and de Leeuw, J.: Evidence for gammacerane as an indicator of water column strati?cation, Geochim. Cosmochim. Ac., 59, 1895-1900, 1995.

Sinninghe Damsté, J. S., Kuypers, M. M. M., Pancost, R. D., and Schouten, S.: The carbon isotopic response of algae, (cyano)bacteria, archaea and higher plants to the late Cenomanian perturbation of the global carbon cycle: Insights from biomarkers in black shales from the Cape Verde Basin (DSDP Site 367), Org. Geochem., 39, 1703-1718, 2008.

Sinninghe Damsté, J. S., van Bentum, E. C., Reichart, G.-J., Pross, J., and Schouten, S.: $\mathrm{A} \mathrm{CO}_{2}$ decrease-driven cooling and increased latitudinal temperature gradient during the midCretaceous Oceanic Anoxic Event 2, Earth Planet. Sc. Lett., 293, 97-103, 2010.

Sluijs, A. and Brinkhuis, H.: A dynamic climate and ecosystem state during the Paleocene-Eocene Thermal Maximum: Inferences from dinoflagellate cyst assemblages on the New Jersey shelf, Biogeosciences, 6, 1755-1781, doi:10.5194/bg-6-17552009, 2009.

Sluijs, A., Pross, J., and Brinkhuis, H.: From greenhouse to icehouse; organic-walled dinoflagellate cysts as paleoenvironmental indicators in the Paleogene, Earth-Sci. Rev. 68, 281-315, 2005.

Snow, L. J., Duncan, R. A., and Bralower, T. J.: Trace element abundances in the Rock Canyon anticline, Pueblo, Colorado, marine sedimentary section and their relationship to Caribbean plateau construction and oxygen anoxic event 2, Paleoceanography, 20, PA3005, doi:10.1029/2004PA001093, 2005.

Thomson, J. D.: Pollen transport and deposition by bumble bees in Erythronium: influences of floral nectar and bee grooming, J. Ecol., 74, 329-341, 1986.

Traverse, A.: Sedimentation of Organic Particles. Cambridge University Press, New York, 544 pp., 1994.

Traverse, A. and Ginsburg, R. N.: Palynology of the surface sediments of Great Bahama Bank, as related to water movement and sedimentation, Mar. Geol., 4, 417-459, 1966.

Tsikos, H., Jenkyns, H. C., Walsworth-Bell, B., Petrizzo, M. R., Forster, A., Kolonic, S., Erba, E., Premoli Silva, I., Baas, M., Wagner, T., and Sinninghe Damsté, J. S.: Carbon-isotope stratigraphy recorded by the Cenomanian-Turonian Oceanic Anoxic Event: correlation and implications based on three key localities, J. Geol. Soc. London, 161, 711-719, 2004.

Turgeon, S. C. and Creaser, R. A.: Cretaceous oceanic anoxic event 2 triggered by a massive magmatic episode, Nature, 454, 323326, 2008.

Van Helmond, N. A. G. M., Sluijs, A., Reichart, G. J., Sinninghe Damsté, J. S., Slomp, C. P., and Brinkhuis, H.: A perturbed hydrological cycle during Oceanic Anoxic Event 2, Geology, 42, 123-126, 2014.

Versteegh, G. J. M. and Zonneveld, K. A. F.: Use of selective degradation to separate preservation from productivity, Geology, 30, 615-618, 2002.

Voigt, S., Gale, A. S., and Voigt, T.: Sea-level change, carbon cycling and palaeoclimate during the Late Cenomanian of northwest Europe; An integrated palaeoenvironmental analysis, Cretaceous Res., 27, 836-858, 2006.

Voigt, S., Erbacher, J., Mutterlose, J., Weiss, W., Westerhold, T., Wiese, F., Wilmsen, M., and Wonik, T.: The CenomanianTuronian of the Wunstorf section (north Germany): Global stratigraphic reference section and new orbital time scale for oceanic anoxic event 2, Newsl. Stratigr., 43, 65-89, 2008.

Voigt, S., Gale, A. S., and Flögel, S.: Mid latitude shelf seas in the Cenomanian-Turonian greenhouse world: Temperature evolution and North Atlantic circulation, Paleoceanography, 19, PA4020. doi:10.1029/2004PA001015, 2014.

Wall, D., Dale, B., Lohmann, G. P., and Smith, W. K.: The environment and climatic distribution of dinoflagellate cysts in mod- 
ern marine sediments from regions in the North and South Atlantic Oceans and adjacent seas, Mar. Micropaleontol, 2, 121200, 1977.

Weijers, J. W. H., Schouten, S., Spaargaren, O. C., and Sinninghe Damsté, J. S.: Occurrence and distribution of tetraether membrane lipids in soils: Implications for the use of the $\mathrm{TEX}_{86}$ proxy and the BIT index, Org. Geochem., 37, 1680-1693, 2006.

Wilmsen, M.: Sequence stratigraphy and palaeoceanography of the Cenomanian stage in northern Germany, Cretaceous Res., 24, 525-568, 2003.

Zheng, X.-Y., Jenkyns, H. C., Gale, A. S., Ward, D. J., and Henderson, G. M.: Changing ocean circulation and hydrothermal inputs during Oceanic Anoxic Event 2 (Cenomanian-Turonian): Evidence from $\mathrm{Nd}$-isotopes in the European shelf sea, Earth Planet. Sc. Lett., 375, 338-348, 2013.
Zonneveld, K. A. F., Versteegh, G. J. M., and De Lange, G. J.: Preservation of organic walled dinoflagellate cysts in different oxygen regimes: a $10000 \mathrm{yr}$ natural experiment, Mar. Micropaleontol., 29, 393-405, 1997.

Zonneveld, K. A. F., Versteegh, G. J. M., and De Lange, G. J.: Palaeoproductivity and post-depositional aerobic organic matter decay reflected by dinoflagellate cyst assemblages of the Eastern Mediterranean S1 sapropel, Mar. Geol., 172, 181-195, 2001. 